\title{
Design, Synthesis and Biological Evaluation of dihydropyrimidine derivatives as potential anticancer agents
}

\author{
Jamelah S. Al-Otaibi ${ }^{\mathrm{a}, \mathrm{b}}$, Tarek M. EL Gogary ${ }^{\mathrm{c}}$ and Diaa A. Ibrahim ${ }^{\mathrm{c}, \mathrm{d}^{*}}$ \\ ${ }^{a}$ Department of Chemistry, College of Science, Princess Nourah bint Abdulrahman \\ University, Riyadh 11951, Saudi Arabia \\ ${ }^{b}$ Deanship of Scientific Research, Princess Nora Bint Abdul Rahman University, Saudi Arabia

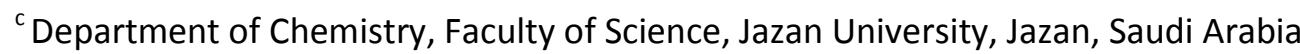 \\ ${ }^{\mathrm{d}}$ National Organization for Drug Control and Research, Cairo, Egypt
}

\begin{abstract}
:
CDK2, which plays a vital role as a regulator of cell growth, is one of the intensely studied TK targets of anticancer inhibitors. The present investigation dealt with design (docking and binding energy), which used to select the promising proposed compounds for the synthesis of novel, diverse 14 pyrido[2,3-d]pyrimidine derivatives as potential anticancer agents targeting CDK2. All the newly synthesized compounds were screened for their anticancer activity against MCF-7 and $\mathrm{CaCO} 2$ and 14 compounds were found to be active. Compounds $\mathbf{6 c}$ and $8 \mathbf{d}$ showed significant activity with $\mathrm{IC}_{50}$ values 7.4 and 5.5 on MCF-7 respectively. Most of the synthesized compounds were subjected to enzyme assay (CDK2 TK) for measuring their inhibitory activity. The preliminary results revealed that compound $\mathbf{8 d}$, which proves potent inhibitory activity toward tumor growth and potent activity on the CDK2 TK enzyme with $89 \%$ inhibition compared to ATP would be a potential anticancer agent.
\end{abstract}

\section{Keywords:}

pyrido[2,3-d] pyrimidines, CDK2 inhibitors, Docking study, Binding energy, Antiproliferative activity

\section{Introduction:}

The cyclin-dependent kinases $(\mathrm{Cdks})$ are a family of serine/threonine protein kinases whose members are small proteins $(\sim 34-40 \mathrm{kDa})$ composed of slightly more than the catalytic core joint by all protein kinases. By classification, all Cdks share the feature that their enzymatic initiation requires the binding of a regulatory cyclin subunit. In utmost cases, full initiation also needs phosphorylation of a threonine residue near the kinase active site. Gathered evidence displayed that overexpression of CDK2 would 
cause the irregular regulation of cell-cycle, which would be straightly associated with hyperproliferation in cancer cells. Accordingly, CDK2 was observed as a possible therapeutic mark for cancer treatment. The finding of therapeutic agents, based upon the principle of inhibiting kinases, is not insignificant. Controlling the activity of protein kinases by low-molecular-weight compounds capable of interfering with either ligand binding (in the case of RTPKs) or with protein substrate binding has confirmed to be very tough [1-3].

Thus, targeting the catalytic site of kinases with ATP competitive inhibitors seems to be the most hopeful approach for drug intervention, while two major problems should be overcome: access to the intracellular targets and discernment of inhibition.

Uracil and its annulated derivatives like pyrido[2,3-d]pyrimidines and pyrimido[4,5d]pyrimidines, characterize vital classes of heterocyclic compounds with biological significance, as they have similarity with pteridine system [4-6]. Numerous derivatives of these scaffolds show a wider range of pharmacological properties; e.g., Inhibitory activities against 5-phosphoribosyl-1-pyrophosphate synthetase [7], dihydrofolate reductases [8], and the tyrosine kinase of the epidermal growth factor receptor [9] have been completely confirmed. Recently, compounds such as RS25344 and CP-77059 having the pyridopyrimidine moiety displayed excellent PDE-4 inhibitory activity [10].

As a part of our program devoted to developing highly expedient, selective and potent anticancer agents targeting CDK2, [11-15] we describe herein the design, an effective and quick method for the synthesis of novel pyrido[2,3- $d]$ pyrimidines as CDK2 inhibitors.

\section{Results and Discussion}

\subsection{Design:}

\subsubsection{Design of test molecules}

The design of targeted compounds 2,5-disubstitutedpyrido[2,3-d]pyrimidine derivatives were derived from the structural optimization of the reference compound ATP which depends on the following two strategies: the reported SAR and molecular modeling studies. The bidentate hydrogen bonds of adenine with Hinge Region was replaced by $\mathrm{N} 1$ and $\mathrm{N} 8$ of pyrido[2,3-d]pyrimidine system, which could form the same hydrogen bonds. Adenine of ATP was bioisosterically replaced with pyrido[2,3- 
d]pyrimidine to occupy the adenine region in the binding pocket. The phosphate binding region was replaced by substituted phenyl moiety. The sugar pocket was replaced by phenyl group at position 5 of pyrido[2,3-d]pyrimidine. The hydrophobic groups at position 2 of pyrido[2,3-d]pyrimidinewas added to occupy the hydrophobic region II, which not occupied by ATP. These hydrophobic groups contain sulfonyl or hydroxyl groups to form H-bonds with the solvent exposure area (Fig.1).

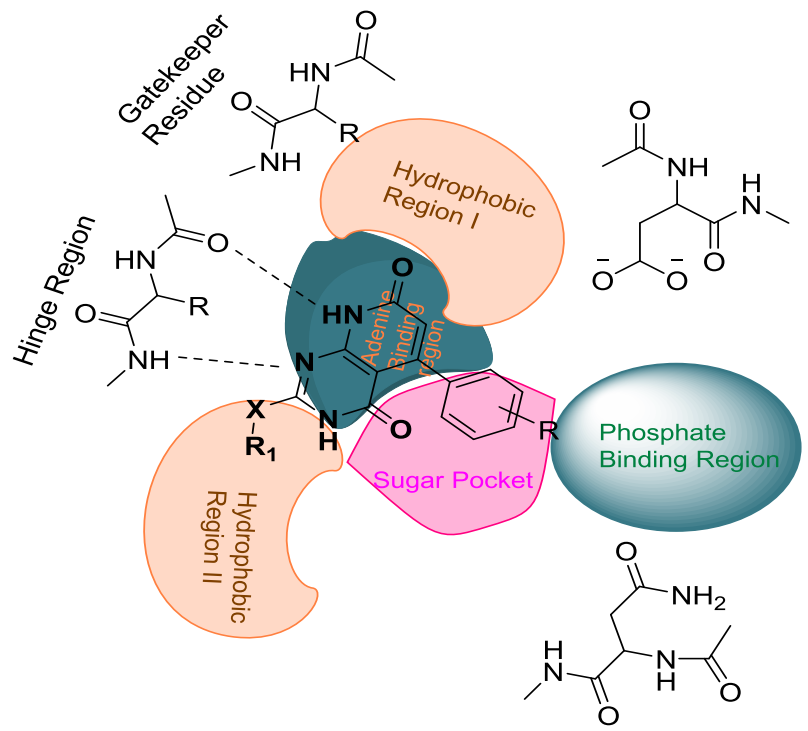

Fig1: The proposed interaction features of pyrido[2,3-d]pyrimidines with ATP active site

\subsubsection{Ligand Preparation}

The three-dimensional structures of all proposed CDK2 inhibitors were prepared using the Ligand preparation module of Discovery Studio tools. The bond orders of these ligands were corrected and the ligands 'cleaned' through preparation specifying a $\mathrm{pH}$ of $6.5-8.5$. There is a possibility that tautomeric forms interact differently with the binding site and one of the tautomers interacts more strongly relative to the other forms. Hence, most probable tautomers of the compounds were chosen based on their interactions with the proteins in the X-ray structures. In the final stage of Ligand preparation, the compounds were energy minimized with CHARMm forcefield.

\subsubsection{Molecular docking and binding energy calculations}

The CDK2 protein structure was gained from the RCSB Protein Data Bank (PDB; 2a4l) [16]. Protein Structure was organized using Discovery Studio (DS 2.0) software package [17]. The unacceptable or absent residues were added, and the structures were aligned via the protein structure alignment component. Hydrogen atoms were assigned, and the structure was minimized by means of CHARMm force field to relax 
the backbone and to eliminate the clashes. For validation of the docking procedures, the native ligand Roscovitine was redocked in its respective CDK2/CyclinA2 active site. The docking results showed the same interaction features as Roscovitine in its native crystal structure and the RMSD was found to be 0.52 . The proposed compounds with promising binding energy values were selected for synthesis. (Table $1)$.

Table 1: The newly synthesized compounds with their docking scores and binding energy compared with Roscovitine as a reference.

\begin{tabular}{|c|c|c|}
\hline Code & Docking Score & Binding energy \\
\hline Roscovitine & -10.31 & -59.33 \\
\hline 6a & -7.398 & -38.522 \\
\hline 6b & -5.436 & -49.157 \\
\hline 6c & -8.356 & -52.78 \\
\hline 6d & -7.709 & -22.283 \\
\hline $8 a$ & -7.444 & -41.393 \\
\hline $8 b$ & -7.922 & -46.161 \\
\hline $8 c$ & -6.769 & -47.779 \\
\hline $8 d$ & -8.112 & -50.732 \\
\hline $9 a$ & -8.917 & -48.936 \\
\hline $9 b$ & -8.825 & -29.117 \\
\hline $9 c$ & -9.435 & -50.569 \\
\hline $9 d$ & -9.317 & -29.076 \\
\hline $13 a$ & -5.754 & -32.70 \\
\hline $13 b$ & -6.224 & -15.742 \\
\hline
\end{tabular}

Docking studies of the proposed compounds in CDK2/CyclinA2 active site revealed that most of the proposed compounds conserved the coordination of $\mathrm{C}=\mathrm{O}$ group of pyridone ring system in $\mathrm{H}$-bond formation with LEU83 and Pyridone $\mathrm{NH}$ with GLU81(fig. 2). 

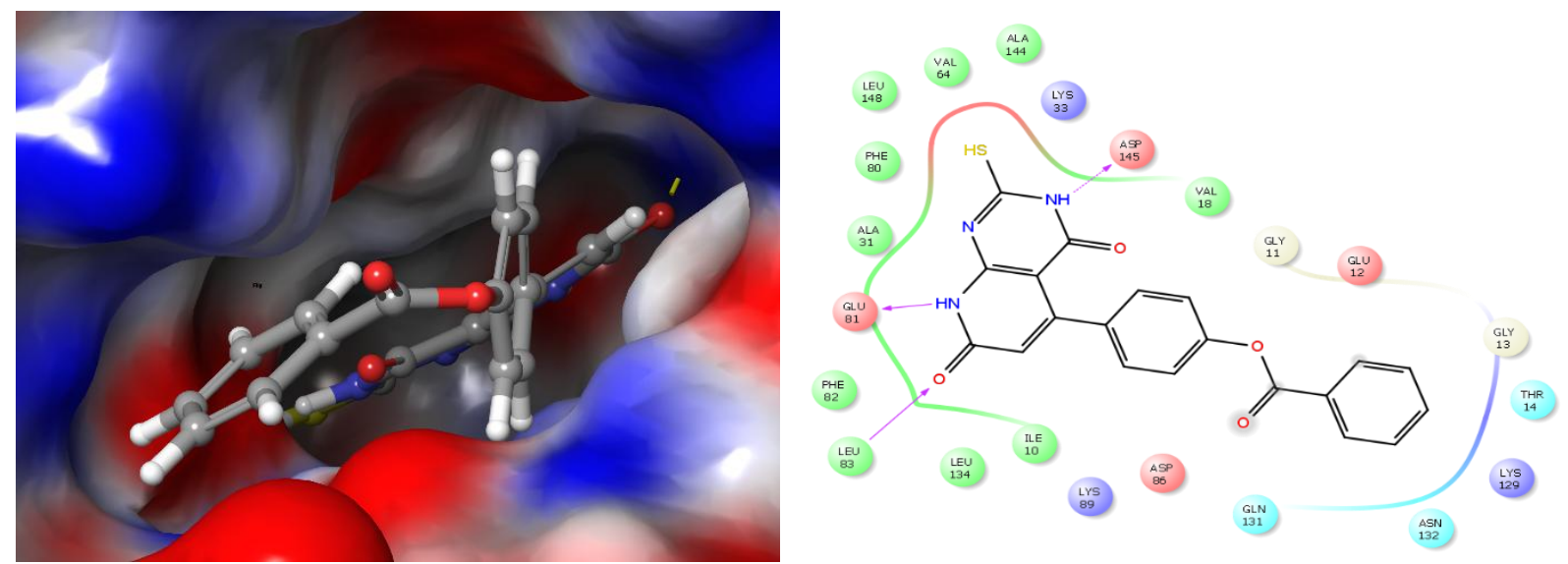

Fig2: 3D and 2D interactions of compound $\mathbf{6 c}$ with ATP active site of CDK2

Introduction of sulfa moiety in position 5 of pyrido[2,3-d]pyrimidine in compounds 8d enhances the binding energy value, while introducing it in compound $\mathbf{6 d}$ and $9 \mathbf{d}$ had no effect because the $\mathrm{SCH}_{3}$ group in compound $\mathbf{8 d}$ occupied the hydrophobic pocket in ATP binding site, which pushes the sulfa moiety toward the sugar pocket and makes 2 hydrogen bonds with THR14 and LYS129(Fig. 3). Also, introducing a sulfanilamide moiety at position 2 enhance the binding energy due to the more favorable interactions with the active site (Fig4).
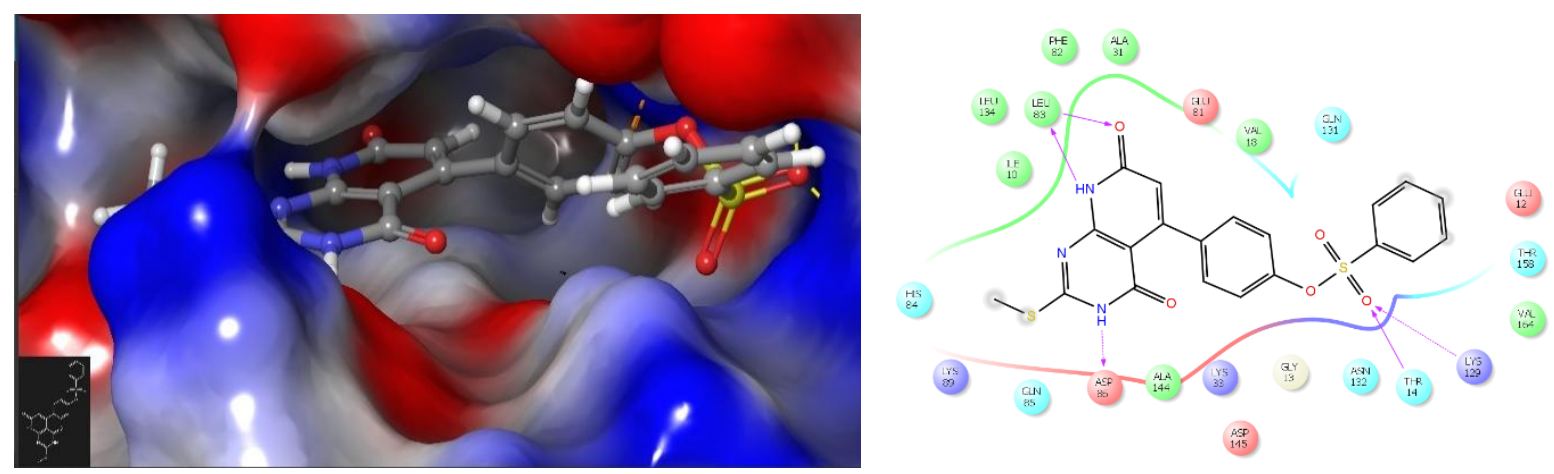

Fig3: 3D and 2D interactions of compound 8d with ATP active site of CDK2
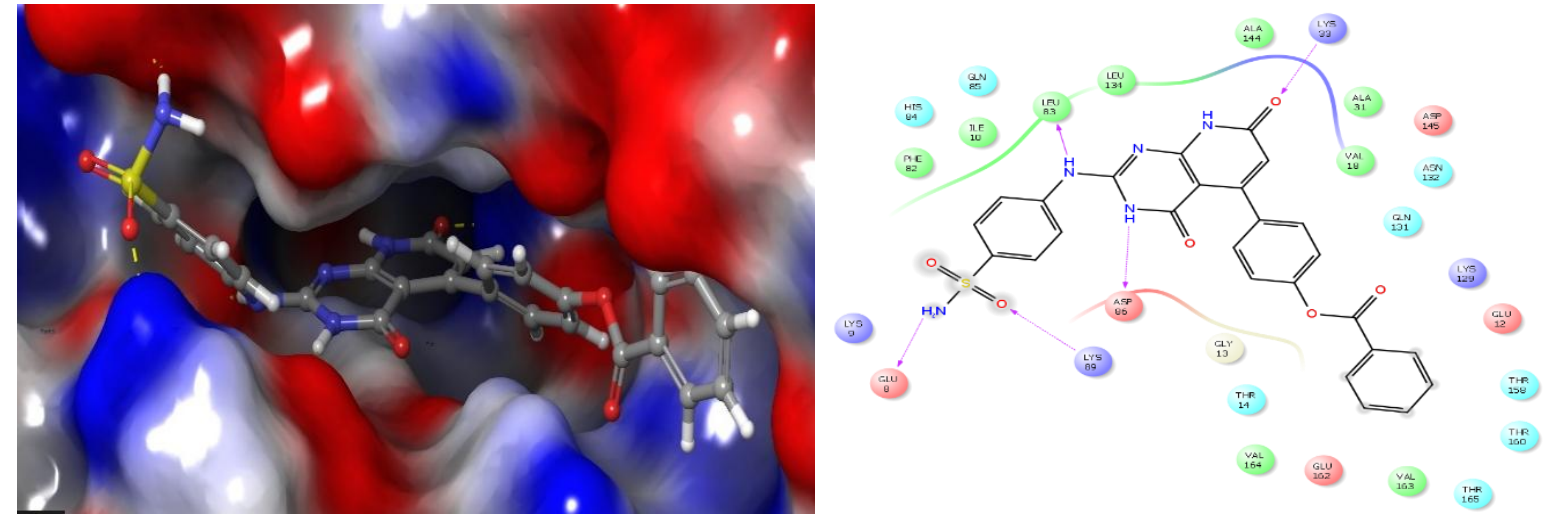

Fig4: 3D and 2D interactions of compound 9cwith ATP active site of CDK2

\subsection{Chemistry:}


The synthetic approach to obtain pyrido[2,3-d]pyrimidine derivatives were shown in Schemes 1, 3 and 4. The starting compound 6-amino-2-thioxo-2,3-dihydropyrimidin4-one, 1, was prepared by reaction of ethyl cyanoacetate with thiourea in presence of sodium ethoxide [18], which reacted with variously substituted arylidene malonic acids [18] to form a series of pyrido[2,3-d]pyrimidines.

Regarding to the options for its reactivity, electron deficient alkene could simply add on in a Michael way and could have been isolated or decarboxylated to yield uracil linked 5-alkene based carboxylic acids 3 or 4 . Here in our work, none of the three compounds 3-5 could occur but we obtained pyridines $\mathbf{6}$ as the only product (Scheme $1)$. 


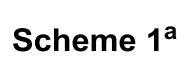

(1)<smiles>[R]c1ccccc1C(c1c(N)[nH]c(=S)[nH]c1=O)C(C(=O)O)C(=O)O</smiles>

3<smiles>[R]c1ccccc1C(CC(=O)O)c1c(N)[nH]c(=S)[nH]c1=O</smiles><smiles>[R]c1ccccc1-c1c(C(=O)O)c(=O)[nH]c2[nH]c(=S)[nH]c(=O)c12</smiles><smiles>[R]c1ccccc1-c1cc(=O)[nH]c2[nH]c(=S)[nH]c(=O)c12</smiles><smiles>[R]c1cccc(/C=C/C(=O)O)c1</smiles>

a) Reagent and condition: (i) DMF, Piperidine, RT, Reflux

The structure of the product is assigned as $\mathbf{6}$ on the basis of IR, ${ }^{1} \mathrm{H}$ NMR, and mass spectra. The ${ }^{1} \mathrm{H}$ NMR spectra recorded in DMSO-d6 showed a multiplet at $\delta$ 7.346.89for aromatic protons. The $\mathrm{NH}$ protons showed a singlet at $\delta 12.8,11.8$ and at 10.7, also a new $\mathrm{CH}$ proton of pyridine resonate as a singlet at $\delta 6.20$. The IR spectra clearly showed absorption for NHs at 3420,3330 and $3195 \mathrm{~cm}^{-1}$. The two $\mathrm{C}=\mathrm{O}$ bands were observed at $1690,1660 \mathrm{~cm}^{-1}$. In mass spectrum, a strong molecular ion peak was obtained at the corresponding molecular weight for compound 6. The alternative 
structure of product 3, 4 and 5 (Scheme 1) is easily ruled out as no broad-band between 1710-1720 $\mathrm{cm}^{-1}$ was observed for the $\mathrm{C}=\mathrm{O}$ function of acid. Final confirmation of structure came from mass where a strong molecular ion peak was observed at $287(\mathrm{M}+\mathrm{H})^{+}$for $\mathbf{6 a}$. The benzalmalonic acid employed in this reaction was prepared by condensation of substituted benzaldehyde with malonic acid in THF using piperidine as a catalyst. ${ }^{1} \mathrm{H}$ NMR spectra of benzalmalonic acid showed a singlet at $\delta 7.52$ for vinyl proton and phenyl protons appeared as a multiplet at $\delta 7.10$ 7.42 .

Plausibly reaction must have proceeded via Michael addition it's difficult to confirm whether decarboxylation occurred before cyclization or after cyclization Scheme 2. To prove it we tried to react cinnamic acids 7 with 6 -amino thiouracil neither there is Michael addition, nor any other product formation takes place and the starting materials were recovered. So evidently, arylidinemalonic acids 2a-g undergoes Michael addition followed by cyclization then decarboxylation and oxidation to yield 6 (scheme 2). The plausible mechanism is as shown below:

Scheme 2

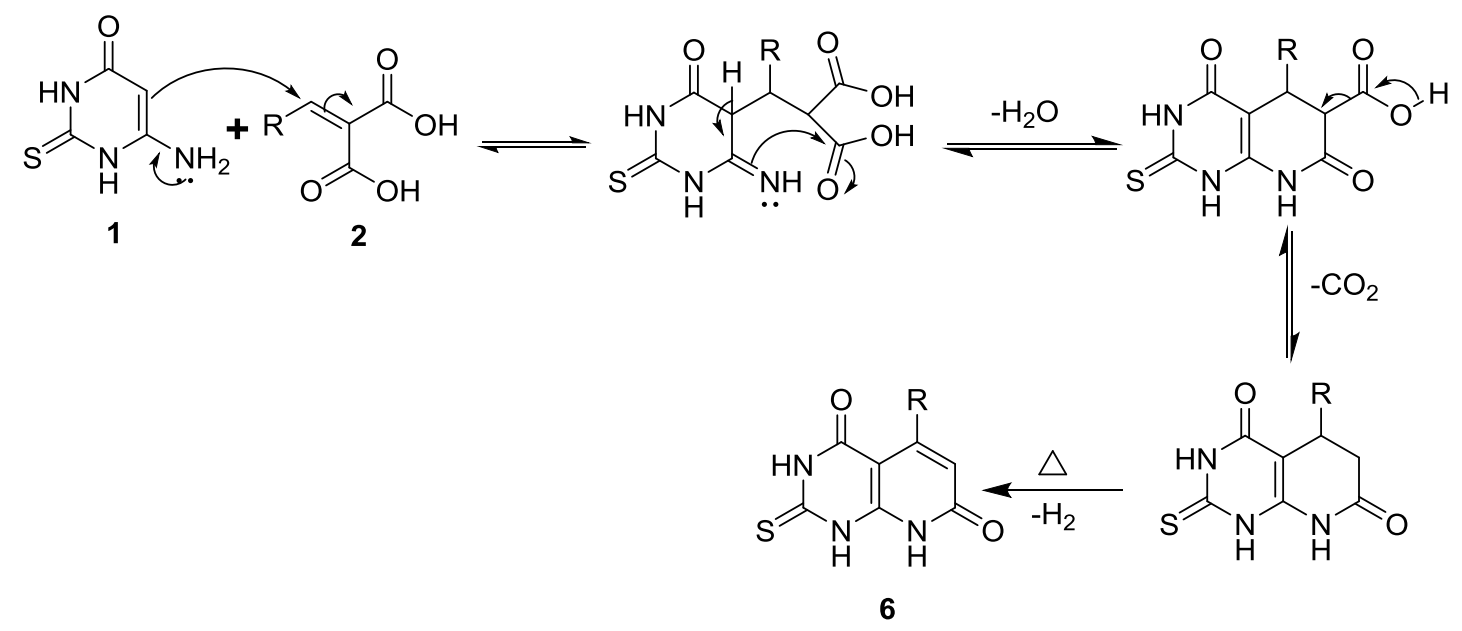

Another confirmation for that the cyclization occurred before decarboxylation, was obtained from quantum mechanics calculations. Compounds 3 and $\mathbf{4}$ were optimized (first the best tautomer was selected then the best conformer was chosen for optimization using semi-Empirical method) by DF theory with B3LYP method and 6$31 \mathrm{G}$ as basis set and the calculations showed that compound $\mathbf{3}$ is more stable than compound 4 (the difference in energy was $495.06 \mathrm{KJ}$ ) as shown in Fig5. 


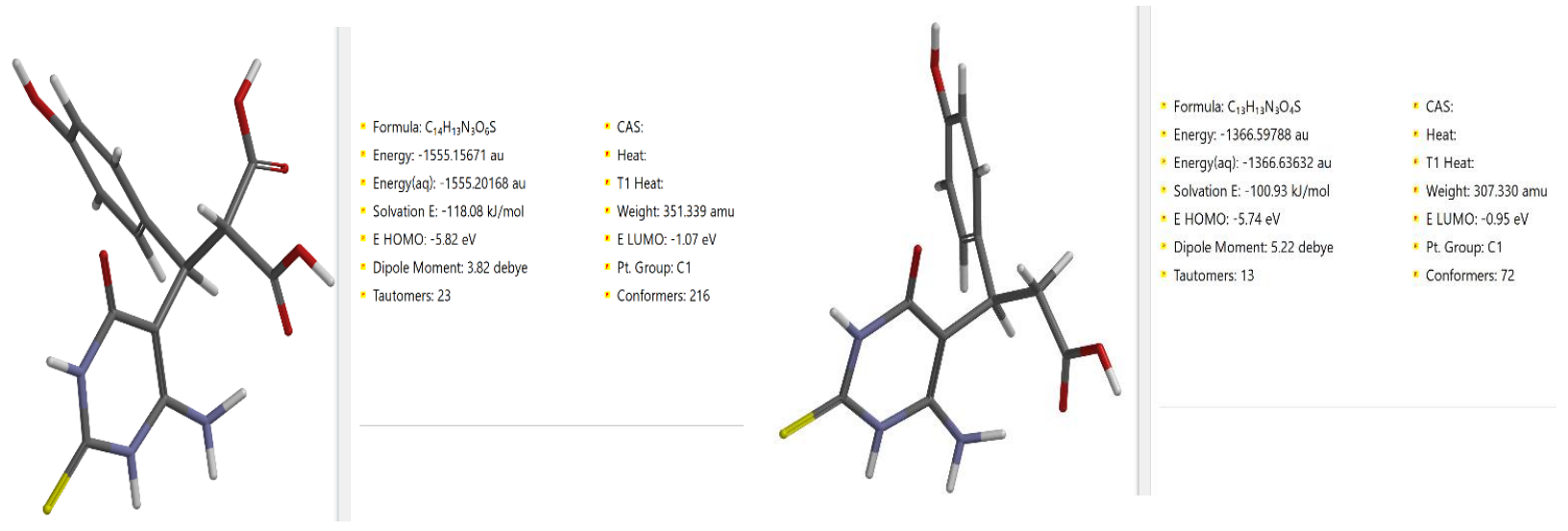

Fig5: Optimized structures of compound 3 and 4 by DFT(B3LYP/6-31G)

To simplify the synthetic work, we carried out the reaction in a multicomponent way by stirring the appropriate aldehyde with malonic acid in DMF in presence of Piperidine as a catalyst for $1 \mathrm{~h}$. then amino thiouracil was added and the reaction mixture was refluxed for 6-8 hrs. and we managed to obtain the target compounds in high yields.

In a trial to optimize the biological results, we prepared compound 9 by alkylation of compound 6 in basic medium then amination of compound 8 with sulfanilamide in refluxing DMF (Scheme3).

\section{Scheme: $3^{\mathrm{a}}$}<smiles>[R]c1ccccc1-c1cc(=O)[nH]c2nc(Nc3ccc(S(N)(=O)=O)cc3)[nH]c(=O)c12</smiles>

a) Reagent and condition: (i) $\mathrm{CH}_{3} \mathrm{l}, \mathrm{NaOH}$, stirring; (ii) Sulfanilamide, $\mathrm{DMF}, \mathrm{HCl}$, Reflux

To make another variation, we tried to prepare 7-aminopyrido[2,3-d]pyrimidine derivatives by reaction of 6-aminothiouracil 1 with various arylidene cyanoacetic acid [19] but the only product was 6-aminouracil-5-arylpropanenitriles (Scheme 4). Here are once more numerous possibilities, arylidene cyanoacetic acids may undertake Michael addition and then cyclize by an attack of the nucleophilic amino group on cyanide function or carboxyl may be tangled in cyclization to yield $\mathbf{1 1}$ and $\mathbf{1 2}$ 
respectively (Scheme 4). We surprise that neither of the two possibilities was not achieved and compound13was obtained, which seems to be the result of initial Michael addition and fast decarboxylation therein prior to any cyclization and thus we successfully isolated a novel set of 6-aminouracil-5-aryl propanenitriles. The reaction is fairly general and product $\mathbf{1 3}$ was isolated in good yields.

Scheme $4^{a}$

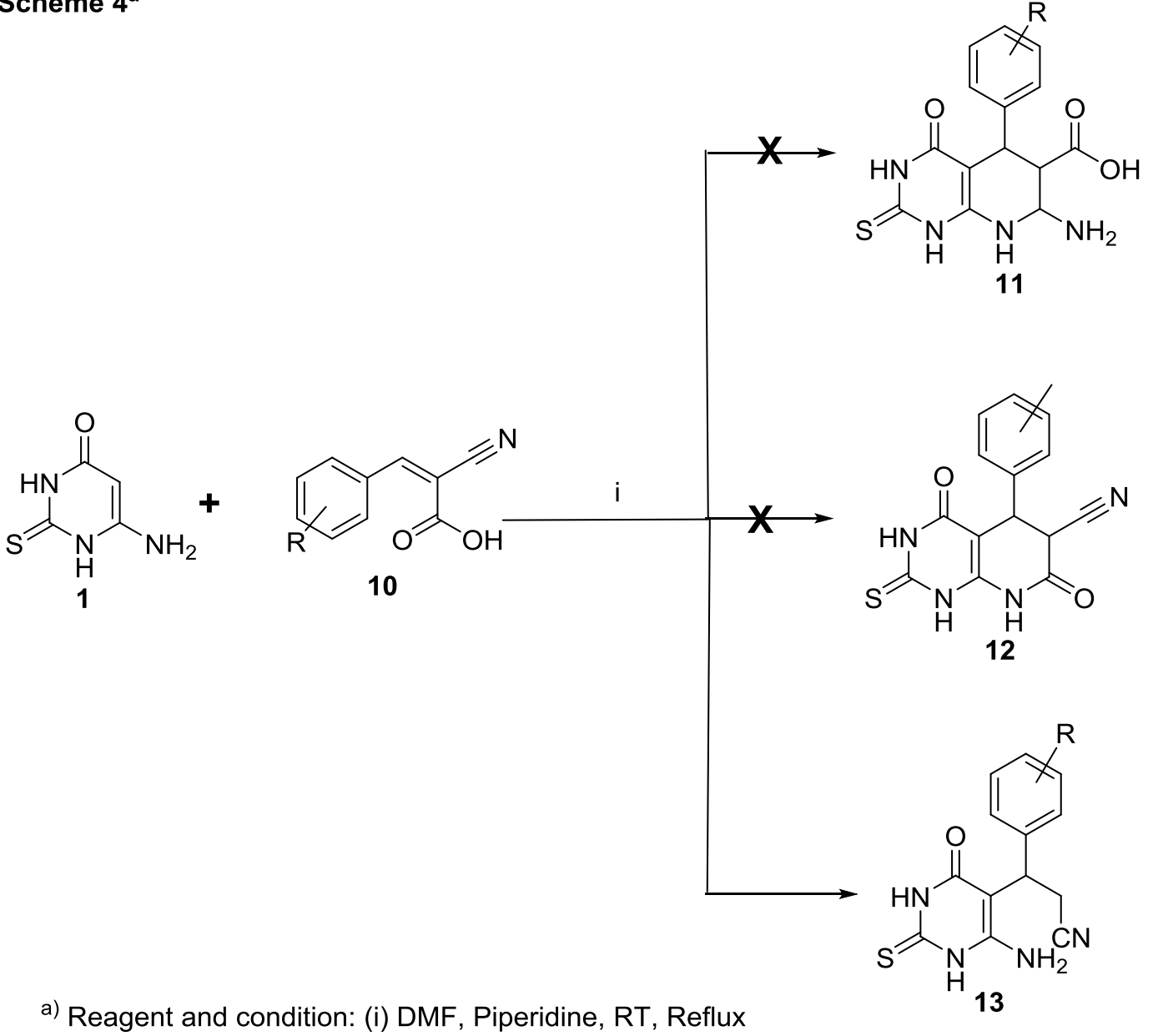

The structure of compound 13 was established by IR, which showed a new strong peak at $2220 \mathrm{Cm}^{-1}$ due to $\mathrm{CN}$ and 1HNMR, which showed one triplet signal at $\delta 4.2$ corresponding to $\mathrm{CH}$ and one doublet signal at $\delta 2.9-2.8$ due to $\mathrm{CH}_{2}$. Finally, the mass spectrum showed a strong molecular ion peak at the corresponding molecular weight of compound $\mathbf{1 3}$.

\subsection{Biology}

Kinases inhibition and antitumor data of the newly synthesized compounds were reported in Table 2.

Table (2): Anticancer and CDK2 Activities of the newly synthesized compounds

\begin{tabular}{|c|c|c|c|c|}
\hline \multirow{2}{*}{ Compds } & \multicolumn{2}{|c|}{$\mathrm{IC}_{50}(\boldsymbol{\mu M})$} & \multirow{2}{*}{$\begin{array}{l}\text { \% inhibition } \\
\text { CDK2 }\end{array}$} & \multirow{2}{*}{$\begin{array}{c}\text { \% inhibition } \\
\text { VEGFR2 }\end{array}$} \\
\hline & MCF-7 & $\mathrm{CaCO} 2$ & & \\
\hline $6 a$ & 37.5 & 41.6 & 56 & 8 \\
\hline $6 \mathrm{~b}$ & 25.6 & 31.4 & 80 & 13 \\
\hline $6 c$ & 7.4 & 18.0 & 85 & 17 \\
\hline
\end{tabular}




\begin{tabular}{|c|c|c|c|c|}
\hline 8a & 26.4 & 21.2 & 83 & 10 \\
\hline $\mathbf{8 b}$ & 36.8 & 21.1 & 88 & 21 \\
\hline 8c & 38.4 & 21.4 & 65 & 23 \\
\hline $\mathbf{8 d}$ & 5.5 & 4.2 & 89 & 18 \\
\hline 9a & 38.4 & 16.1 & 75 & 12 \\
\hline 9b & 21.7 & 14.9 & 90 & 15 \\
\hline 9c & 6.4 & 3.2 & 91 & 22 \\
\hline 9d & 61.3 & 38.8 & 23 & 11 \\
\hline $\mathbf{1 3 a}$ & 65.2 & 205.5 & 21 & 27 \\
\hline 13b & 55.6 & 36.6 & 41 & 17 \\
\hline
\end{tabular}

The newly synthesized compounds exhibited effective CDK2 inhibitory activity with good to effective inhibition profile. Most of the newly synthesized compounds showed quite potent inhibitory efficiency against CDK2/cyclinA, with inhibition percent in the range of 56 to 90, except for compounds 13a and 13b. Compounds $\mathbf{6 c}$, 8d, and 9c showed the highest inhibitory activity and the highest antitumor activities against MCF-7 and $\mathrm{CaCO}_{2}$ cell lines and could be used as lead compounds for further studies and optimization. The biological results were in good correlation with the modeling studies. In general, the derivatives with $\mathrm{SCH}_{3}$ group were more active than the derivatives with $\mathrm{C}=\mathrm{S}$ and the derivatives with sulfanilamide group were the most active one except for 9d. All these results showed a good correlation between the modeling studies and the biological results. Compound 9d may be inactive because of its geometrical shape of the two sulfanilamide groups, which prevent it from being buried well in the active site. All compounds were tested against VEGFR2 and none of them showed any significant inhibition, which showed some selectivity towards CDK2.

\section{Conclusions}

A series of novel pyrido[2,3-d]pyrimidine derivatives linked to various substitutions at positions 2 and 5 were docked into the active site of CDK2 and the binding energy was calculated and used for selection of the best pose. The promising compounds according to binding energy calculations were synthesized and evaluated as inhibitors of CDK2/CyclinA and as antitumor agents against MCF-7 and CaCO2. The established compounds exhibited an actual upright inhibition of CDK2. Compounds 6c, 8d, and 9c showed good selectivity towards CDK2 and a very good activity against breast and Colon cancer, so they can be used as a lead compound for further optimization. The biological results were in good correlation with the modeling 
studies. In general, the derivatives with $\mathrm{SCH}_{3}$ group were more active than the derivatives with $\mathrm{C}=\mathrm{S}$ and the derivatives with sulfanilamide group were the most active as suggested by the modeling studies. All the newly produced compounds exhibited selectivity towards CDK2.

\section{Acknowledgments}

The authors would like to thank the Deanship of Scientific Research, Princess Noura Bint Abdulrahman University for funding this study.

\section{Experiments:}

\subsection{Chemistry}

All chemicals used were purchased from Sigma-Aldrich (USA)and SD-fine (India) and used without further purification. Separation of the compounds by column chromatography was carried out using silica gel 60 (200-300 mesh ASTM, E. Merck). The quantity of silica gel used was 50-100 times the weight charged on the column. Then, the reactions were monitored using TLC and visualized under UV light $(254 \mathrm{~nm})$. Melting points (uncorrected)were determined on an XT4 MP apparatus. Mass spectra were recorded on a Varian MAT 112 Spectrometer at Al-Azhar University. Analytical data (IR) were performed at the Micro-Analytical Data Center of Cairo University and National Research Center. Some of the ${ }^{1} \mathrm{H}$ NMR spectra were recorded on a Variant spectrometer $500 \mathrm{MHz}$, at the Micro-Analytical Data Center of Mansoura University and the main laboratories of the chemical war, while others were recorded at National Research Center, at $25{ }^{\circ} \mathrm{C}$ with TMS and solvent signals allotted as internal standards. Chemical shifts were reported in ppm (d). Elemental analyses were performed on a CHNS-O-Rapid instrument in the Micro-Analytical Data Center at the main laboratories of the chemical war. Compounds were $\mathbf{1}^{18}, \mathbf{2}^{19}$ and $\mathbf{1 0}^{20}$ synthesized according to reported methods.

\section{Preparation of arylidene malonic acids $(2)^{17}$}

Malonic acid (5.2 g, 0.05 mole) and substituted benzaldehyde ( 0.05 mole) were taken in $20 \mathrm{~mL}$ of tetrahydrofuran (THF). To this stirred solution, added few drops of piperidine and continued stirring for further 1 hour. Evaporation of excess solvent under reduced pressure gave the colorless solid which was purified from ethanol to obtained pure product in $87 \%$ yield. 
5-substituted phenyl-2-thioxo-2,3-dihydropyrido[2,3-d]pyrimidine-4,7-dione Derivatives (6)

A mixture of arylidene malonic acids $\mathbf{2 a - g}(10 \mathrm{mmol})$, uracil compound $\mathbf{1}$ (10 mmol) in $15 \mathrm{ml}$ nitrobenzene was stirred at $150^{\circ} \mathrm{C}$ for 3.0 to $4.5 \mathrm{~h}$. After completion of reaction (monitored via TLC), the reaction mixture was cooled to room temperature and excess solvent was removed under vacuum. The solid thus obtained was recrystallized from methanol to afford pyrido[2,3-d]pyrimidines 6 in good yields.

\section{5-(4-hydroxyphenyl)-2-thioxo-2,3-dihydropyrido[2,3-d]pyrimidine-4,7-dione 6a}

Yellowish white powder. Yield $=80 \% . \mathrm{Mp}=216-219^{\circ} \mathrm{C} . \mathrm{IR}\left(\mathrm{cm}^{-1}\right), 3421(\mathrm{OH})$, 3335, 3269, 3189 (3NH), 1671 (C=O amide); ${ }^{1} \mathrm{H}$ NMR (500 MHz, DMSO- $\left.d_{6}\right) \delta 12.88$ (s, 1H,NH exchangeable with $\mathrm{D}_{2} \mathrm{O}$ ), 11.87 (s, 1H,NH exchangeable with $\mathrm{D}_{2} \mathrm{O}$ ), 10.62 (s, 1H,NH exchangeable with $\left.\mathrm{D}_{2} \mathrm{O}\right), 8.67$ (s, 1H,OH exchangeable with $\left.\mathrm{D}_{2} \mathrm{O}\right), 7.34$ (d, $J=9.0 \mathrm{~Hz}, 2 \mathrm{H}), 6.80(\mathrm{~d}, J=9.0 \mathrm{~Hz}, 2 \mathrm{H}), 6.27$ (s, 1H, H3 Pyridine). ${ }^{13} \mathrm{C}$ NMR (125 MHz, DMSO- $\left.d_{6}\right) \delta 175.38,164.67,157.40,156.29,155.85,153.03,131.12,130.17$, 114.18, 110.58, 86.48; MS $(\mathrm{m} / \mathrm{z})=287.29,\left[\mathrm{M}^{+1}\right]=288.21$; Anal. Calcd for $\mathrm{C}_{13} \mathrm{H}_{9} \mathrm{~N}_{3} \mathrm{O}_{3} \mathrm{~S}$ : C, 54.35; H, 3.16; N, 14.63. Found: C, 53.87; H, 3.67; N, 15.17.

5-(4-hydroxy-3-methoxyphenyl)-2-thioxo-2,3-dihydropyrido[2,3-d]pyrimidine-

\section{4,7-dione $6 b$}

colorless crystalline. Yield $=70 \% . \mathrm{Mp}=238-240{ }^{\circ} \mathrm{C}$; IR $\left(\mathrm{cm}^{-1}\right), 3361(\mathrm{OH}), 3320$, 3280, 3195 (3NH), 1660 (C=O amide) $;{ }^{1} \mathrm{H}$ NMR (500 MHz, DMSO-d6) $\delta 12.65$ (s, 1H,NH exchangeable with $\left.\mathrm{D}_{2} \mathrm{O}\right), 11.88\left(\mathrm{~s}, 1 \mathrm{H}, \mathrm{NH}\right.$ exchangeable with $\left.\mathrm{D}_{2} \mathrm{O}\right), 10.73$ (s, $1 \mathrm{H}, \mathrm{NH}$ exchangeable with $\left.\mathrm{D}_{2} \mathrm{O}\right), 8.85\left(\mathrm{~s}, 1 \mathrm{H}, \mathrm{OH}\right.$ exchangeable with $\left.\mathrm{D}_{2} \mathrm{O}\right), 7.23-$ $7.14(\mathrm{~d}, \mathrm{~J}=8.5 \mathrm{~Hz}, 1 \mathrm{H}), 6.86$ (d, J = 8.5 Hz, 1H), 6.26 (s, 1H, H3 Pyridine), 3.84 (s, 3H, OCH3).13C NMR (125 MHz, DMSO-d6) $\delta$ 175.38, 164.66, 156.28, 155.77, 152.49, 147.97, 146.66, 130.85, 121.41, 113.44, 112.55, 110.49, 86.44, 56.02; MS $(\mathrm{m} / \mathrm{z})=317$; Anal. Calcd for C14H11N3O4S: C, 52.99; H, 3.49; N, 13.24. Found: C, $53.47 ; \mathrm{H}, 3.17 ; \mathrm{N}, 13.57$.

\section{4-(4,7-dioxo-2-thioxo-1,2,3,4,7,8-hexahydropyrido[2,3-d]pyrimidin-5-yl)phenyl benzoate $6 \mathrm{c}$}

Light brown powder. Yield $=74 \% . \mathrm{Mp}=191-194^{\circ} \mathrm{C} ; \mathrm{IR}\left(\mathrm{cm}^{-1}\right), 3330,3260,3202$ (3NH), 1710 (C=O ester), 1660 (C=O amide); ${ }^{1} \mathrm{H}$ NMR (500 MHz, DMSO- $\left.d_{6}\right) \delta 12.97$ (s, $1 \mathrm{H}, \mathrm{NH}$ exchangeable with $\left.\mathrm{D}_{2} \mathrm{O}\right), 11.92\left(\mathrm{~s}, 1 \mathrm{H}, \mathrm{NH}\right.$ exchangeable with $\left.\mathrm{D}_{2} \mathrm{O}\right)$, $10.55\left(\mathrm{~s}, 1 \mathrm{H}, \mathrm{NH}\right.$ exchangeable with $\left.\mathrm{D}_{2} \mathrm{O}\right), 8.13(\mathrm{dd}, J=7.7,1.5 \mathrm{~Hz}, 2 \mathrm{H}), 7.68-7.61$ (m, 3H, ArH), $7.54-7.48(\mathrm{~d}, 2 \mathrm{H}, J=9.2 \mathrm{~Hz}, 2 \mathrm{H}), 7.31-7.25(\mathrm{~d}, 2 \mathrm{H}, J=9.2 \mathrm{~Hz}$, 
2H), 6.31 (s, 1H, H3 Pyridine). ${ }^{13} \mathrm{C}$ NMR (125 MHz, DMSO- $\left.d_{6}\right) \delta 175.45,165.38$, $164.92,156.29,155.79,153.04,151.72,133.77,132.76,130.32,129.86$ (d, $J=10.5$ $\mathrm{Hz})$, 128.96, 119.87, 110.46, 86.48; MS (m/z) = 391.40; Anal. Calcd for $\mathrm{C}_{20} \mathrm{H}_{13} \mathrm{~N}_{3} \mathrm{O}_{4} \mathrm{~S}$ : C, 61.37; H, 3.35; N, 10.74. Found: C, 61.47; H, 3.13; N, 10.57 .

\section{4-(4,7-dioxo-2-thioxo-1,2,3,4,7,8-hexahydropyrido[2,3-d]pyrimidin-5-yl)phenyl}

\section{benzenesulfonate $6 \mathrm{~d}$}

Off white powder. Yield $=67 \% . \mathrm{Mp}=178-181^{\circ} \mathrm{C} ; \mathrm{IR}\left(\mathrm{cm}^{-1}\right), 3410,3302,3250$ (3NH), 1660 (C=O amide), $1350(\mathrm{~S}=\mathrm{O}) ;{ }^{1} \mathrm{H}$ NMR (500 MHz, DMSO- $\left.d_{6}\right) \delta 13.29$ (s, $1 \mathrm{H}, \mathrm{NH}$ exchangeable with $\left.\mathrm{D}_{2} \mathrm{O}\right), 11.83\left(\mathrm{~s}, 1 \mathrm{H}, \mathrm{NH}\right.$ exchangeable with $\left.\mathrm{D}_{2} \mathrm{O}\right), 10.27$ (s, 1H, NH exchangeable with $\left.\mathrm{D}_{2} \mathrm{O}\right), 7.89-7.84(\mathrm{dd}, J=7.9,1.4 \mathrm{~Hz}, 2 \mathrm{H}), 7.78-7.74(\mathrm{~m}$, $3 \mathrm{H}, \operatorname{ArH}), 7.41(\mathrm{~d}, J=8.9 \mathrm{~Hz}, 2 \mathrm{H}), 7.39 \quad(\mathrm{~d}, J=8.9 \mathrm{~Hz}, 2 \mathrm{H}), 6.29$ (s, 1H, H3 Pyridine).${ }^{13} \mathrm{C}$ NMR (125 MHz, DMSO- $\left.d_{6}\right) \delta 175.38,164.68,156.29,155.98,153.03$, 149.58, 136.86, 133.07 (d, $J=11.7 \mathrm{~Hz}), 129.22$ (d, $J=9.3 \mathrm{~Hz}), 128.31,119.51$, 110.53, 86.48; MS (m/z) = 427.45; Anal. Calcd for $\mathrm{C}_{19} \mathrm{H}_{13} \mathrm{~N}_{3} \mathrm{O}_{5} \mathrm{~S}_{2}: \mathrm{C}, 53.39 ; \mathrm{H}, 3.07$; N, 9.83. Found: C, 52.97; H, 3.23; N, 10.17 .

\section{2-(methylthio)-5-substituted phenylpyrido[2,3-d]pyrimidine-4,7-dione8}

To a solution of $7(0.033 \mathrm{~mol})$ in $0.83 \mathrm{~N} \mathrm{NaOH}(65 \mathrm{~mL})$ was added $\mathrm{CH}_{3} \mathrm{I}(5.0 \mathrm{~g})$ and the reaction mixture was stirred at RT for $2 \mathrm{~h}$. The solution was treated with charcoal, filtered and the filtrate was acidified with acetic acid. The crude product was filtered and suspended in $100 \mathrm{~mL}$ of $\mathrm{H}_{2} \mathrm{O}$ and the $\mathrm{PH}$ adjusted to 9 by ammonium hydroxide to dissolve any unreacted starting materials. The ammonical solution was filtered, washed with $\mathrm{H}_{2} \mathrm{O}$ and collected to afford compound $\mathbf{8}$.

\section{5-(4-hydroxyphenyl)-2-(methylthio) pyrido[2,3-d]pyrimidine-4,7-dione8a}

Off white powder. Yield $=87 \% . \mathrm{Mp}=188-191{ }^{\circ} \mathrm{C}$; IR $\left(\mathrm{cm}^{-1}\right), 3420(\mathrm{OH}), 3312,3260$ (2NH), 1670 (C=O amide); ${ }^{1} \mathrm{H}$ NMR (500 MHz, DMSO-d $) \delta 11.81(\mathrm{~s}, 1 \mathrm{H}, \mathrm{NH}$ exchangeable with $\left.\mathrm{D}_{2} \mathrm{O}\right), 11.38\left(\mathrm{~s}, 1 \mathrm{H}, \mathrm{NH}\right.$ exchangeable with $\left.\mathrm{D}_{2} \mathrm{O}\right), 8.67(\mathrm{~s}, 1 \mathrm{H}, \mathrm{OH}$ exchangeable with $\left.\mathrm{D}_{2} \mathrm{O}\right), 7.30(\mathrm{~d}, J=9.0 \mathrm{~Hz}, 2 \mathrm{H}), 6.80(\mathrm{~d}, J=9.0 \mathrm{~Hz}, 2 \mathrm{H}), 6.14(\mathrm{~s}$, 1H, H3 Pyridine), 2.53 (s, 3H, $\left.\mathrm{SCH}_{3}\right) .{ }^{13} \mathrm{C}$ NMR (125 MHz, DMSO- $d_{6}$ ) $\delta 164.71$, $159.79,159.23(\mathrm{~d}, J=16.9 \mathrm{~Hz}), 157.97,157.16,130.97,127.32,114.12,86.87$, 12.81; MS $(\mathrm{m} / \mathrm{z})=301.32$; Anal. Calcd for $\mathrm{C}_{14} \mathrm{H}_{11} \mathrm{~N}_{3} \mathrm{O}_{3} \mathrm{~S}: \mathrm{C}, 55.81 ; \mathrm{H}, 3.68 ; \mathrm{N}, 13.95$. Found: C, 55.37; H, 3.33; N, 13.47.

\section{5-(4-hydroxy-3-methoxyphenyl)-2-(methylthio)pyrido[2,3-d]pyrimidine-4,7-} dione8b 
colorless crystalline. Yield $=90 \% . \mathrm{Mp}=210-213^{\circ} \mathrm{C}$; IR $\left(\mathrm{cm}^{-1}\right), 3421(\mathrm{OH}), 3280$, 3195 (2NH), 1690 (C=O amide); ${ }^{1} \mathrm{H}$ NMR (500 MHz, DMSO-d $) \delta 12.09$ (s, 1H, NH exchangeable with $\left.\mathrm{D}_{2} \mathrm{O}\right), 11.79\left(\mathrm{~s}, 1 \mathrm{H}, \mathrm{NH}\right.$ exchangeable with $\left.\mathrm{D}_{2} \mathrm{O}\right), 8.84(\mathrm{~s}, 1 \mathrm{H}, \mathrm{OH}$ exchangeable with $\left.\mathrm{D}_{2} \mathrm{O}\right), 7.24-7.18(\mathrm{~d}, J=8.8 \mathrm{~Hz}, 1 \mathrm{H}), 7.21(\mathrm{~s}, 1 \mathrm{H}, \mathrm{ArH}), 6.89$ (d, $J$ $=8.8 \mathrm{~Hz}, 1 \mathrm{H}), 6.16(\mathrm{~s}, 1 \mathrm{H}, \mathrm{H} 3$ Pyridine $), 3.84\left(\mathrm{~s}, 3 \mathrm{H}, \mathrm{OCH}_{3}\right), 2.51\left(\mathrm{~s}, 3 \mathrm{H}, \mathrm{SCH}_{3}\right) .{ }^{13} \mathrm{C}$ NMR (125 MHz, DMSO- $\left.d_{6}\right) \delta 164.64,159.45$ - 159.21 (m), 157.16, 147.99, 146.40, $127.56,122.22,113.77(\mathrm{~d}, J=9.5 \mathrm{~Hz}), 113.44,86.90,55.99,12.78 ; \mathrm{MS}(\mathrm{m} / \mathrm{z})=$ 331.35; Anal. Calcd for $\mathrm{C}_{15} \mathrm{H}_{13} \mathrm{~N}_{3} \mathrm{O}_{4} \mathrm{~S}$ : C, 54.37; H, 3.95; N, 12.68. Found: C, 54.07; $\mathrm{H}, 3.83 ; \mathrm{N}, 12.44$.

\section{4-(2-(methylthio)-4,7-dioxo-3,4,7,8-tetrahydropyrido[2,3-d]pyrimidin-5- yl)phenyl benzoate 8c}

brown powder. Yield $=82 \% . \mathrm{Mp}=170-174{ }^{\circ} \mathrm{C} ; \mathrm{IR}\left(\mathrm{cm}^{-1}\right), 3310,3240(2 \mathrm{NH}), 1715$ $(\mathrm{C}=\mathrm{O}$ ester $), 1670(\mathrm{C}=\mathrm{O}$ amide $){ }^{1} \mathrm{H}$ NMR $\left(500 \mathrm{MHz}, \mathrm{DMSO}-d_{6}\right) \delta 11.91(\mathrm{~s}, 1 \mathrm{H}, \mathrm{NH}$ exchangeable with $\left.\mathrm{D}_{2} \mathrm{O}\right), 11.48\left(\mathrm{~s}, 1 \mathrm{H}, \mathrm{NH}\right.$ exchangeable with $\left.\mathrm{D}_{2} \mathrm{O}\right), 8.12(\mathrm{~d}, J=6.3$ $\mathrm{Hz}, 2 \mathrm{H}), 7.68-7.57$ (m, 3H, ArH), 7.48 (d, $J=9.2 \mathrm{~Hz}, 2 \mathrm{H}), 7.31$ (d, $J=9.1 \mathrm{~Hz}, 2 \mathrm{H})$, 6.20 (s, 1H, H6 pyridine), $2.55\left(\mathrm{~s}, 3 \mathrm{H}, \mathrm{SCH}_{3}\right) .{ }^{13} \mathrm{C}$ NMR $\left(125 \mathrm{MHz}, \mathrm{DMSO}-d_{6}\right) \delta$ $165.41,164.69,159.86,159.31,156.93,151.72$, 133.68, 131.04, 130.32, 129.82, 128.96, 119.84, 114.01, 87.08, 12.79; MS $(\mathrm{m} / \mathrm{z})=405.43$; Anal. Calcd for $\mathrm{C}_{21} \mathrm{H}_{15} \mathrm{~N}_{3} \mathrm{O}_{4} \mathrm{~S}: \mathrm{C}, 62.21 ; \mathrm{H}, 3.73$; N, 10.36. Found: C, 62.07; H, 3.33; N, 10.13.

\section{4-(2-(methylthio)-4,7-dioxo-3,4,7,8-tetrahydropyrido[2,3-d]pyrimidin-5-}

\section{yl)phenyl benzenesulfonate $8 d$}

Colorless powder. Yield $=91 \% . \mathrm{Mp}=160-162^{\circ} \mathrm{C} ; \mathrm{IR}\left(\mathrm{cm}^{-1}\right), 3320,3230(2 \mathrm{NH}), 1690$ (C=O amide), $1330(\mathrm{~S}=\mathrm{O}) ;{ }^{1} \mathrm{H}$ NMR $\left(500 \mathrm{MHz}, \mathrm{DMSO}-d_{6}\right) \delta 11.93(\mathrm{~s}, 1 \mathrm{H}, \mathrm{NH}$ exchangeable with $\left.\mathrm{D}_{2} \mathrm{O}\right), 11.42\left(\mathrm{~s}, 1 \mathrm{H}, \mathrm{NH}\right.$ exchangeable with $\left.\mathrm{D}_{2} \mathrm{O}\right), 7.87(\mathrm{dd}, J=$ 8.0, $1.5 \mathrm{~Hz}, 2 \mathrm{H}), 7.79-7.67$ (m, 3H, ArH), 7.39 (d, $J=8.8 \mathrm{~Hz}, 2 \mathrm{H}), 7.36$ (d, $J=8.8$ $\mathrm{Hz}, 2 \mathrm{H}) 6.16$ (s, 1H, H6 Pyridine), 2.50 (s, 3H, $\left.\mathrm{SCH}_{3}\right) .{ }^{13} \mathrm{C}$ NMR (125 MHz, DMSO$\left.d_{6}\right) \delta 164.69,159.86,159.31,156.77,149.58,136.88,133.10,130.44,129.41,129.20$, 128.27, 119.51, 114.01, 87.08, 12.81; MS $(\mathrm{m} / \mathrm{z})=441.48$; Anal. Calcd for $\mathrm{C}_{20} \mathrm{H}_{15} \mathrm{~N}_{3} \mathrm{O}_{5} \mathrm{~S}_{2}$ : C, 54.41; H, 3.42; N, 9.52. Found: C, 54.27; H, 3.23; N, 9.23.

4-((5-(substituted phenyl)-4,7-dioxo-3,4,7,8-tetrahydropyrido[2,3-d]pyrimidin-2yl)amino)benzenesulfonamide 9

To a mixture of compound 8 (5 mmol) and sulfanilamide (10 mmol. $1.72 \mathrm{~g})$ was added Conc. $\mathrm{HCl}(1 \mathrm{~mL})$ and the reaction mixture was refluxed at $200{ }^{\circ} \mathrm{C}$ for $12 \mathrm{hrs}$. 
After the reaction was completed, the product was collected by filtration and washed well with boiling $\mathrm{H}_{2} \mathrm{O}$ and EtOH to afford the amino derivatives 9

\section{4-((5-(4-hydroxyphenyl)-4,7-dioxo-3,4,7,8-tetrahydropyrido[2,3-d]pyrimidin-2-}

yl) amino)benzenesulfonamide 9a

Yellow powder. Yield $=80 \% . \mathrm{Mp}=236-239^{\circ} \mathrm{C} \cdot \mathrm{IR}\left(\mathrm{cm}^{-1}\right), 3425(\mathrm{OH}), 3305,3280$, 3240, (2NH), 3189, $3151\left(\mathrm{NH}_{2}\right), 1681$ (C=O amide); ${ }^{1} \mathrm{H}$ NMR (500 MHz, DMSO- $\left.d_{6}\right)$ $\delta 11.58\left(\mathrm{~s}, 1 \mathrm{H}, \mathrm{NH}\right.$ exchangeable with $\left.\mathrm{D}_{2} \mathrm{O}\right), 11.29(\mathrm{~s}, 1 \mathrm{H}, \mathrm{NH}$ exchangeable with $\left.\mathrm{D}_{2} \mathrm{O}\right), 10.60$ (s, 1H, NH exchangeable with $\left.\mathrm{D}_{2} \mathrm{O}\right), 8.97$ (s, $1 \mathrm{H}, \mathrm{OH}$ exchangeable with $\left.\mathrm{D}_{2} \mathrm{O}\right), 7.72(\mathrm{~d}, J=8.7 \mathrm{~Hz}, 2 \mathrm{H}) 7.69(\mathrm{~d}, J=8.7 \mathrm{~Hz}, 2 \mathrm{H}), 7.33(\mathrm{~d}, J=8.6 \mathrm{~Hz}, 2 \mathrm{H}), 7.15$ (s, 2H, $\mathrm{NH}_{2}$ exchangeable with $\left.\mathrm{D}_{2} \mathrm{O}\right), 6.81(\mathrm{~d}, J=8.6 \mathrm{~Hz}, 2 \mathrm{H}), 6.22(\mathrm{~s}, 1 \mathrm{H}, \mathrm{H} 6$ Pyridine); ${ }^{13} \mathrm{C}$ NMR (125 MHz, DMSO- $\left.d_{6}\right) \delta 164.20,161.74,158.96,157.66,153.78$, 152.44, 143.75, 137.33, 130.96, 127.84, 127.21, 119.13, 114.53, 114.01, 91.16; MS $(\mathrm{m} / \mathrm{z})=425.42$; Anal. Calcd for $\mathrm{C}_{19} \mathrm{H}_{15} \mathrm{~N}_{5} \mathrm{O}_{5} \mathrm{~S}: \mathrm{C}, 53.64 ; \mathrm{H}, 3.55 ; \mathrm{N}, 16.46$. Found: $\mathrm{C}$, $53.37 ; \mathrm{H}, 3.33 ; \mathrm{N}, 16.23$.

\section{4-((5-(4-hydroxy-3-methoxyphenyl)-4,7-dioxo-3,4,7,8-tetrahydropyrido[2,3-}

\section{d]pyrimidin-2-yl)amino)benzenesulfonamide9b}

Yellowish white crystals. Yield $=79 \% . \mathrm{Mp}=240-243{ }^{\circ} \mathrm{C} ; \mathrm{IR}\left(\mathrm{cm}^{-1}\right), 3440(\mathrm{OH})$, 3315, 3280, 3230, (2NH), 3190, $3161\left(\mathrm{NH}_{2}\right), 1675$ (C=O amide); ${ }^{1} \mathrm{H}$ NMR (500 MHz, DMSO- $\left.d_{6}\right) \delta 11.48\left(\mathrm{~s}, 1 \mathrm{H}, \mathrm{NH}\right.$ exchangeable with $\left.\mathrm{D}_{2} \mathrm{O}\right), 10.85(\mathrm{~s}, 1 \mathrm{H}, \mathrm{NH}$ exchangeable with $\left.\mathrm{D}_{2} \mathrm{O}\right), 10.30\left(\mathrm{~s}, 1 \mathrm{H}, \mathrm{NH}\right.$ exchangeable with $\left.\mathrm{D}_{2} \mathrm{O}\right), 8.39(\mathrm{~s}, 1 \mathrm{H}, \mathrm{OH}$ exchangeable with $\left.\mathrm{D}_{2} \mathrm{O}\right), 7.71(\mathrm{~d}, J=8.8 \mathrm{~Hz}, 2 \mathrm{H}), 7.61(\mathrm{~d}, J=8.8 \mathrm{~Hz}, 2 \mathrm{H}), 7.23$ (s, $1 \mathrm{H}, \mathrm{ArH}), 7.01(\mathrm{~d}, J=8.4 \mathrm{~Hz}, 1 \mathrm{H}), 7.01\left(\mathrm{~s}, 2 \mathrm{H}, \mathrm{NH}_{2}\right), 6.90(\mathrm{~d}, J=8.4 \mathrm{~Hz}, 1 \mathrm{H}), 6.21$ (s, 1H, H6 Pyridine), 3.81 (s, 3H, $\left.\mathrm{OCH}_{3}\right) .{ }^{13} \mathrm{C}$ NMR (125 MHz, DMSO- $\left.d_{6}\right) \delta 164.14$, $161.73,158.45,153.78,152.36,147.89,146.79,143.97,137.12,127.87,127.53$, 122.19, 119.13, 114.47, 113.74, 113.45, 90.65, 55.97; MS (m/z) = 455.45; Anal. Calcd for $\mathrm{C}_{20} \mathrm{H}_{17} \mathrm{~N}_{5} \mathrm{O}_{6} \mathrm{~S}: \mathrm{C}, 52.74 ; \mathrm{H}, 3.76 ; \mathrm{N}, 15.38$. Found: C, 52.47; H, 3.53; N, 15.26 .

\section{4-(4,7-dioxo-2-((4-sulfamoylphenyl)amino)-3,4,7,8-tetrahydropyrido[2,3-}

\section{d]pyrimidin-5-yl)phenyl benzoate 9c}

Yellow powder. Yield $=69 \% . \mathrm{Mp}=195-197{ }^{\circ} \mathrm{C} . \mathrm{IR}\left(\mathrm{cm}^{-1}\right), 3325,3270,3220$, (3NH), 3190, $3161\left(\mathrm{NH}_{2}\right), 1715$ (C=O ester), 1681 (C=O amide) ${ }^{1} \mathrm{H}$ NMR (500 MHz, DMSO-d6) $\delta 11.56\left(\mathrm{~s}, 1 \mathrm{H}, \mathrm{NH}\right.$ exchangeable with $\left.\mathrm{D}_{2} \mathrm{O}\right), 11.42(\mathrm{~s}, 1 \mathrm{H}, \mathrm{NH}$ 
exchangeable with $\left.\mathrm{D}_{2} \mathrm{O}\right), 10.65\left(\mathrm{~s}, 1 \mathrm{H}, \mathrm{NH}\right.$ exchangeable with $\left.\mathrm{D}_{2} \mathrm{O}\right), 8.13(\mathrm{~d}, \mathrm{~J}=9.0$ $\mathrm{Hz}, 2 \mathrm{H}), 7.72-7.65$ (m, 3H, ArH), 7.70 (d, J = 8.6 Hz, 2H), 7.68 (d, J=8.6, 2H), 7.51 $(\mathrm{d}, \mathrm{J}=8.9 \mathrm{~Hz}, 2 \mathrm{H}), 7.32(\mathrm{~d}, \mathrm{~J}=8.8 \mathrm{~Hz}, 2 \mathrm{H}), 7.06\left(\mathrm{~s}, 2 \mathrm{H}, \mathrm{NH}_{2}\right), 6.26(\mathrm{~s}, 1 \mathrm{H}, \mathrm{H} 6$ Pyridine). ${ }^{13} \mathrm{C}$ NMR (125 MHz, DMSO- $\left.d_{6}\right) \delta 165.40,164.14,161.74,158.92,153.75$, $152.42,152.13,143.98,137.06,133.68,131.08,130.32,129.82,129.12,128.93$, 127.77, 119.91, 119.18, 114.06, 90.69; MS $(\mathrm{m} / \mathrm{z})=529.53$; Anal. Calcd for $\mathrm{C}_{26} \mathrm{H}_{19} \mathrm{~N}_{5} \mathrm{O}_{6} \mathrm{~S}: \mathrm{C}, 58.97 ; \mathrm{H}, 3.62 ; \mathrm{N}, 13.23$. Found: C, 58.46; H, 3.43; N, 13.35 .

\section{4-(4,7-dioxo-2-((4-sulfamoylphenyl)amino)-3,4,7,8-tetrahydropyrido[2,3- d]pyrimidin-5-yl)phenyl benzenesulfonate 9d}

Yellow powder. Yield $=86 \% . \mathrm{Mp}=175-178^{\circ} \mathrm{C} ; \mathrm{IR}\left(\mathrm{cm}^{-1}\right), 3410,3320,3230(2 \mathrm{NH})$, 3199, $3176\left(\mathrm{NH}_{2}\right), 1690$ (C=O amide), 1330 (S=O); ${ }^{1} \mathrm{H}$ NMR (500 MHz, DMSO-d6) $\delta 11.56\left(\mathrm{~s}, 1 \mathrm{H}, \mathrm{NH}\right.$ exchangeable with $\left.\mathrm{D}_{2} \mathrm{O}\right), 11.42$ (s, $1 \mathrm{H}, \mathrm{NH}$ exchangeable with $\left.\mathrm{D}_{2} \mathrm{O}\right), 10.65$ (s, 1H, NH exchangeable with $\left.\mathrm{D}_{2} \mathrm{O}\right), 7.78(\mathrm{~d}, J=7.8 \mathrm{~Hz}, 2 \mathrm{H}), 7.70(\mathrm{~d}, J$ $=8.6 \mathrm{~Hz}, 2 \mathrm{H}), 7.68-7.63(\mathrm{~m}, 3 \mathrm{H}), 7.59(\mathrm{~d}, \mathrm{~J}=8.6 \mathrm{~Hz}, 2 \mathrm{H}), 7.50(\mathrm{~d}, \mathrm{~J}=8.5 \mathrm{~Hz}, 2 \mathrm{H})$, 7.42 (d, J = 8.5 Hz, 2H), 7.21 (s, 2H, NH $\mathrm{NH}_{2}, 5.93$ (s, 1H, H6 Pyridine) ${ }^{13} \mathrm{C}$ NMR (125 MHz, DMSO- $\left.d_{6}\right) \delta 164.14,161.74,158.92,153.75,152.42,149.75,144.01,137.05$, $136.88,132.94,130.38,129.41,129.21,128.32,127.73,119.49,119.16,114.06$, 90.69; MS $(\mathrm{m} / \mathrm{z})=565.58$; Anal. Calcd for $\mathrm{C}_{25} \mathrm{H}_{19} \mathrm{~N}_{5} \mathrm{O}_{7} \mathrm{~S}_{2}$ : C, 53.09; H, 3.39; N, 12.38. Found: C, 53.26; H, 3.51; N, 12.28 .

\section{Preparation of arylidenecyanoacetic acids $(\mathbf{1 0})^{18}$}

Cyanoacetic acid (4.25 g, 0.05 mole) and substituted benzaldehyde ( 0.05 mole) was taken in $20 \mathrm{~mL}$ of tetrahydrofuran (THF). To this stirred solution, added few drops of piperidine and continued stirring for further 1 hour at $50{ }^{\circ} \mathrm{C}$. Evaporation of the excess solvent under reduced pressure gave the solid which was purified from ethanol. Similarly, other arylidene cyanoacetic acids (2a-e) were prepared.

\section{Preparation of 6-aminouracil-5-arylpropanenitriles (13):}

A mixture of arylidene cyanoacetic acids $7(10 \mathrm{mmol})$, uracil compound 1 (10 mmol) in $15 \mathrm{~mL}$ nitrobenzene was stirred at $150{ }^{\circ} \mathrm{C}$ for 2.5 to $4 \mathrm{~h}$. After completion of reaction (monitored by TLC), the reaction mixture was cooled to room temperature and excess solvent was removed under vacuum. The solid thus obtained was recrystallized from ethyl acetate to afford 6-aminouracil-5-arylpropanenitriles $\mathbf{1 0}$ in good yields. The spectral data of products $\mathbf{1 0}$ are given below. 


\section{3-(6-amino-4-oxo-2-thioxo-1,2,3,4-tetrahydropyrimidin-5-yl)-3-(4-}

\section{hydroxyphenyl) propanenitrile 13a}

Gray powder. Yield $=87 \% . \mathrm{Mp}=222-225^{\circ} \mathrm{C} . \mathrm{IR}\left(\mathrm{cm}^{-1}\right), 3411(\mathrm{OH}), 3335,3280$ (NH2), 3269, 3189 (2NH), $2221(\mathrm{CN}), 1671$ (C=O amide); ${ }^{1} \mathrm{H}$ NMR (500 MHz, DMSO- $\left.d_{6}\right) \delta 11.89\left(\mathrm{~s}, 1 \mathrm{H}, \mathrm{NH}\right.$ exchangeable with $\left.\mathrm{D}_{2} \mathrm{O}\right), 11.18(\mathrm{~s}, 1 \mathrm{H}, \mathrm{NH}$ exchangeable with $\left.\mathrm{D}_{2} \mathrm{O}\right), 8.47\left(\mathrm{~s}, 1 \mathrm{H}, \mathrm{OH}\right.$ exchangeable with $\left.\mathrm{D}_{2} \mathrm{O}\right), 7.19(\mathrm{~d}, J=8.8$ $\mathrm{Hz}, 2 \mathrm{H}), 6.97\left(\mathrm{~s}, 2 \mathrm{H}, \mathrm{NH}_{2}\right), 6.72(\mathrm{~d}, J=8.8 \mathrm{~Hz}, 2 \mathrm{H}), 4.27(\mathrm{t}, J=5.6 \mathrm{~Hz}, 1 \mathrm{H}, \mathrm{CH})$, 2.90 - $2.84\left(\mathrm{t}, 2 \mathrm{H}, \mathrm{CH}_{2}\right) .{ }^{13} \mathrm{C}$ NMR $\left(125 \mathrm{MHz}, \mathrm{DMSO}-d_{6}\right) \delta 178.34,157.53,155.68$, $151.99,136.52,129.28,117.87,115.70,80.87,38.51,24.93 ; \mathrm{MS}(\mathrm{m} / \mathrm{z})=288.33$; Anal. Calcd for $\mathrm{C}_{13} \mathrm{H}_{12} \mathrm{~N}_{4} \mathrm{O}_{2} \mathrm{~S}$ : C, 54.16; H, 4.20; N, 19.43. Found: C, 54.36; H, 4.43; N, 19.28 .

\section{3-(6-amino-4-oxo-2-thioxo-1,2,3,4-tetrahydropyrimidin-5-yl)-3-(4-hydroxy-3-}

\section{methoxyphenyl)propanenitrile 13b}

colorless crystalline. Yield $=79 \% . \mathrm{Mp}=208-210{ }^{\circ} \mathrm{C}$; IR $\left(\mathrm{cm}^{-1}\right), 3341(\mathrm{OH}), 3320$, 3290 (NH2), 3250, 3175 (2NH), $2220(\mathrm{CN}), 1675$ (C=O amide); ${ }^{1} \mathrm{H}$ NMR (500 MHz, DMSO- $\left.d_{6}\right) \delta 11.88\left(\mathrm{~s}, 1 \mathrm{H}, \mathrm{NH}\right.$ exchangeable with $\left.\mathrm{D}_{2} \mathrm{O}\right), 11.21(\mathrm{~s}, 1 \mathrm{H}, \mathrm{NH}$ exchangeable with $\left.\mathrm{D}_{2} \mathrm{O}\right), 8.69\left(\mathrm{~s}, 1 \mathrm{H}, \mathrm{OH}\right.$ exchangeable with $\left.\mathrm{D}_{2} \mathrm{O}\right), 6.56\left(\mathrm{~s}, 2 \mathrm{H}, \mathrm{NH}_{2}\right.$ exchangeable with $\left.\mathrm{D}_{2} \mathrm{O}\right), 6.87(\mathrm{~s}, 1 \mathrm{H}, \mathrm{ArH}), 6.89(\mathrm{~d}, J=8.4 \mathrm{~Hz}, 1 \mathrm{H}), 6.76(\mathrm{~d}, J=8.4$ $\mathrm{Hz}, 1 \mathrm{H}), 4.30(\mathrm{t}, J=5.6 \mathrm{~Hz}, 1 \mathrm{H}), 3.83\left(\mathrm{~s}, 3 \mathrm{H}, \mathrm{OCH}_{3}\right), 2.92-2.87\left(\mathrm{~m}, 2 \mathrm{H}, \mathrm{CH}_{2}\right) .{ }^{13} \mathrm{C}$ NMR $\left(125 \mathrm{MHz}, \mathrm{DMSO}-d_{6}\right) \delta 178.34,157.59,152.00,147.62,145.86,137.73$, 121.50, 117.87, 115.48, 112.39, 80.73, 56.13, 38.70, 24.89; MS (m/z) = 318.35; Anal. Calcd for $\mathrm{C}_{14} \mathrm{H}_{14} \mathrm{~N}_{4} \mathrm{O}_{3} \mathrm{~S}$ : C, 52.82; H, 4.43; N, 17.60. Found: C, 52.39; H, 4.63; N, 17.82

\subsection{Biology}

3.2.1. Cytotoxicity (MTT assay)

Human Breast (MCF-7) cancer cells were propagated in $75 \mathrm{~cm} 2$ cell culture flasks using RPMI-1640 medium (Gibco-USA) supplemented with $10 \%$ (v/v) fetal bovine serum (Gibco-USA) and incubated in $5 \%(\mathrm{v} / \mathrm{v}) \mathrm{CO}_{2}$ incubator at a temperature of $37^{\circ} \mathrm{C}$. Confluent cells were detached using $0.25 \%(\mathrm{w} / \mathrm{v})$ trypsin solution and $0.05 \%$ $(\mathrm{v} / \mathrm{v})$ ethylenediaminetetraacetic acid (Gibco-USA) for $5 \mathrm{~min}$. Cells were plated at a concentration of $2 \times 105 \mathrm{cell} / \mathrm{s} / \mathrm{ml}$ in $96-$ well cell culture plates and incubated at a temperature of $37^{\circ} \mathrm{C}$ for 24 hours to achieve confluence. The medium was decanted and fresh medium containing various concentrations of bee venom and Lapatinib was 
added for cytotoxicity determination using colorimetric MTT reduction assay. Dead cells were washed out using phosphate-buffer Edsa-line (PBS), and $50 \mu$ of MTT stock solution $(5 \mathrm{mg} / \mathrm{ml})$ was added to each well. After $4 \mathrm{~h}$ incubation period, the supernatants were discarded and the formazan precipitates were solubilized by addition of $50 \mu 1$ per well of dimethyl sulfoxide (DMSO) or $0.4 \%(\mathrm{v} / \mathrm{v})$ acidified isopropanol. Plates were incubated in the dark for $30 \mathrm{~min}$ at a temperature of $37 \mathrm{oC}$, and absorbance was determined at a wavelength of $570 \mathrm{~nm}$ using microplate reader (Biotek ELX -800, USA). The cell viability percentage was calculated using the following formula:

Cell viability $(\%)=\frac{\text { OD of treated wells x } 100}{\text { OD of control wells }}$

The cell viability (\%) was plotted with the tested bee venom and Lapatinib concentrations. Statistical significance between treated and untreated cells was determined using one way ANOVA. Differences at $\mathrm{P}$ values less than 0.05 were considered significant. The $\mathrm{IC}_{50}$ values of test bee venom and lapatinib were determined using Masterplex-2010 software program. The effect of bee venom and Lapatinib as an anticancer synergetic agent was examined by evaluating the cytotoxic potential of bee venom and Lapatinib in MCF-7 cells pretreated with 25 and $50 \mu \mathrm{g}$ for $24 \mathrm{~h}$. Morphological alterations of cells were analyzed using an inverted microscope (Nikon-Japan).

\subsection{2. in vitro enzymatic assay (CDK2/CyclinA2)}

\subsubsection{Assay Conditions}

The assay was performed using Kinase-Glo Plus luminescence kinase assay kit (Promega). It measures kinase activity by quantitating the amount of ATP remaining in solution following a kinase reaction. The luminescent signal from the assay is correlated with the amount of ATP present and is inversely correlated with the amount of kinase activity.

The compounds were diluted in $10 \%$ DMSO and $5 \mu$ of the dilution was added to a $50 \mu 1$ reaction so that the final concentration of DMSO is $1 \%$ in all of the reactions.

All the enzymatic reactions were conducted at $30{ }^{\circ} \mathrm{C}$ for 40 minutes. The $50 \mu 1$ reaction mixture contains $40 \mathrm{mM}$ Tris, $\mathrm{pH} 7.4,10 \mathrm{mM} \mathrm{MgCl}_{2}, 0.1 \mathrm{mg} / \mathrm{ml} \mathrm{BSA}, 1 \mathrm{mM}$ DTT, $10 \mu \mathrm{M}$ ATP, Kinase substrate and the enzyme. 
After the enzymatic reaction, $50 \mu 1$ of Kinase-Glo Plus Luminescence kinase assay solution (Promega) was added to each reaction and incubate the plate for 5 minutes at room temperature. Luminescence signal was measured using a BioTek Synergy 2 microplate reader.

\subsubsection{Data Analysis}

Kinase activity assays were performed in duplicate at each concentration. The luminescence data were analyzed using the computer software, GraphPad Prism. The difference between luminescence intensities in the absence of Kinase $\left(\mathrm{Lu}_{\mathrm{t}}\right)$ and in the presence of Kinase $\left(\mathrm{Lu}_{\mathrm{c}}\right)$ was defined as $100 \%$ activity $\left(\mathrm{Lu}_{\mathrm{t}}-\mathrm{Lu}_{\mathrm{c}}\right)$. Using luminescence signal $(\mathrm{Lu})$ in the presence of the compound, \% activity was calculated as:

$\%$ activity $=\left\{\left(\mathrm{Lu}_{\mathrm{t}}-\mathrm{Lu}\right) /\left(\mathrm{Lu}_{\mathrm{t}}-\mathrm{Lu}_{\mathrm{c}}\right)\right\} \times 100 \%$, where $\mathrm{Lu}=$ the luminescence intensity in the presence of the compound (all percent activities below zero were shown zero in the table).

\section{Acknowledgement}

This work was supported by the Deanship of Scientific Research, Princess Nourah Bint Abdul Rahman University.

\section{References}

1. Burke, T. R., Jr., Yao, Z.-J., Smyth, M. S., \& Ye, B. (1997). Phosphotyrosyl based motifs in the structure-based design of protein-tyrosine kinasedependent signal transduction inhibitors. Curr. Pharm Design 3, 291-304.

2. Sasaki, S., Hashimoto, T., Obana, N., Yasuda, H., Uehara, Y., \& Maeda, M. (1998). Design of new inhibitors for CDC2 kinase based on a multiple pseudosubstrate structures. Bioorg Med Chem Lett 8, 1019- 1022.

3. Dalgarno, D. C., Metcalf, C. A., III, Shakespeare, W. C., \& Sawyer, T. K. (2000). Signal transduction drug discovery: targets, mechanisms, and structure-based design. CurrOpin Drug DiscovDevel 3, 549-564.

4. E. Lunt. Comprehensive organic chemistry, Vol. 4, Edited by D. Barton, W.D. Ollis. Pergamon, Oxford; UK (1974).

5. J.D. Brown. Comprehensive heterocyclic chemistry, Vol. 3, Edited by A.R. Katritzky, C.W. Rees. Pergamon, Oxford; UK(1984). 
6. Clercq E De and Beraerts R, Specific phosphorylation of 5-ethyl-2'deoxyuridineby herpes simplex virus-infected cells and incorporation into viral DNA.J. Biol. Chem., 262 (31): 14905-14911, (1987).

7. Rewcastle WG, Bridges JA, Fry WD, Rubin RJ, and Denny WA, Tyrosine kinase inhibitors .12. Synthesis and structure-activity-relationships for 6substituted 4-phenylamino)pyrimido[5,4-d]pyrimidines designed as inhibitors of the epidermal growth-factor receptor. J. Med. Chem., 40 (12): 1820-1826, 1997.

8. Fry WD, Becker AM and Switzer LR, Inhibition of human 5-phosphoribosyl1-pyrophosphate synthetase by 4-amino-8- (beta-D-ribofuranosylamino) pyrimido[5,4-d]pyrimidine-5'- monophosphate: evidence for interaction at the ADP allosteric site. Mol. Pharmacol., 47(4):810-815, (1995).

9. Gready EJ, McKinlay C. and Gebauer GM, Synthesis of quaternised 2aminopyrimido[4,5-d]pyrimidin-4(3H)-onesand their biological activity with dihydrofolate reductases. Eur. J.Med.Chem., 38 (7-8): 719-728, (2003).

10. Pagès, L.; Gavaldà, A.; Lehner, M. D., PDE4 inhibitors: a review of current developments (2005-2009). Expert Opin. Ther. Pat.,19 (11), 1501-1519 (2009)

11. Diaa A. I., Julie B., Daniel H. L., Sri K.V., Kevin R. T., Samuel S. A., Donald R. R., and Steven J. S., Design, Synthesis, and X-ray Analysis of a Glycoconjugate Bound to Mycobacterium Tuberculosis Antigen 85C Bioconjugate Chem. 23, 2403-2416 (2012).

12. Rizk E. K., Diaa A. I., Ibrahim M. R., Synthesis of a novel heterocyclic scaffold utilizing 2-cyano-N-(3-cyano-4,6-dimethyl-2-oxopyridin-1-yl) acetamide. ARKIVOC (v) S1-S16(2016).

13. Diaa A. I., Deena S. L., Maysoun Y. Z., Amany W. I., Daniela V., Mariangela C. d., Claudiu T. S., Dalal A. A., Design and synthesis of benzothiazole-6sulfonamides acting highly potent inhibitors of carbonic anhydrase isoforms I, II, IX, and XII. Bioorganic \& Medicinal Chemistry 23 4989-4999(2015).

14. Tarek M. El-Gogary, Interaction of Angelicin with DNA-Bases (III) An ab initio Quantum Chemical, Density Functional Theory and Second-Order MØller-Plesset Perturbational Study. International Journal of Quantum Chemistry 110(8), 1445-1454 (2010). 
15. Jamelah S. A. and Tarek M. E., Synthesis of novel anthraquinones: Molecular structure, molecular chemical reactivity descriptors and interactions with DNA as antibiotic and anti-cancer drugs. Journal of Molecular Structure 1130 799809(2017).

16. http://www.rcsb.org/pdb/explore/explore.do?structureId=2A4L.

17. Discovery Studio 2.0. Accelrys, Inc., San Diego, CA, (2003).

18. Koppel, H. C.; Springler, R. H.; Robins, R. K.; Cheng, C. C., Pyrimidines. I. Synthesis of Pyrimidinethiols. J. Org. Chem. 1961, 26 ,792.

19. Randeep K. S., Kaul V.K. and Manrao M.R., Synthesis and nematicidal activity of benzalmalonic acid. Indian Journal of Agricultural Chemistry, 37(2 \&3), 51-54; (2004).

20. Anjali S., Sharma J. R., and Mangat R., Chemoselective reaction of cyanoacetic acid with benzal-4-acetylanilines and fungitoxicity of products. J. Chem. Sci., Vol. 121 (4): 449-453, (2009), 